\title{
KUALITAS LARUTAN PENGENCER DAN KUALITAS SEMEN DOMBA PADA TEMPERATUR PENYIMPANAN YANG BERBEDA
}

\author{
Winangun, K., Toha , dan A. Yusrina \\ Fakultas Peternakan, Universitas Padjadjaran \\ e-mail : kwinangun@yahoo.com
}

\begin{abstract}
The semen extender contain nutrients for survival of spermatozoa during storage process. The storage temperature can affect the oxidation level of subtances in diluent and can cause damage spermatozoa. The study aimed to examine the effect of temperature on extender quality and semen quality of local ram's. The material used in this research is tris egg yolk extender and semen local ram's. Data were analyzed using ANOVA and follow by Duncan multiple range test. Tris egg yolk extender wasstored at different temperature namely storage at temperature $7^{\circ} \mathrm{C}, 28^{\circ} \mathrm{C}$ dan $37^{\circ} \mathrm{C}$. The variable in this research is extender quality such as density, viscosity, $\mathrm{pH}$, and semen quality such as motility and viability sperm. The result of this research shows that the effect of temperature storage significant different $(P<0,05)$ on extender quality and semen quality local ram's. It can be concluded that tris egg yolk extender was stored at temperature $7^{\circ} \mathrm{C}$ had the higest value of density $(1,0069$ $(\mathrm{g} / \mathrm{ml}))$, viscosity $(2,8537(\mathrm{~mm} 2 / \mathrm{s}) /(\mathrm{cSt}))$ and $\mathrm{pH}(6,5)$, and than sperm be able to survive for 13 days.
\end{abstract}

\begin{abstract}
ABSTRAK
Pengencer semen mengandung nutrisi bagi kelangsungan hidup spermatozoa selama proses penyimpanan. Temperatur penyimpanan dapat mempengaruhi tingkat oksidasi zat-zat pada pengencer serta menyebabkan kerusakan spermatozoa. Penelitian ini bertujuan untuk mengetahui pengaruh temperatur penyimpanan terhadap kualitas larutan pengencer dan kualitas semen domba. Materi yang digunakan dalam penelitian ini adalah larutan tris kuning telur dan semen segar domba lokal. Data dianalisis menggunakan Anova dan di uji lanjut menggunakan uji Duncan. Larutan tris kuning telur disimpan pada temperatur yang berbedabeda yaitu penyimpanan pada temperatur $7^{\circ} \mathrm{C}, 28^{\circ} \mathrm{C}$ dan $37^{\circ} \mathrm{C}$. Variabel yang diukur pada penelitian ini yaitu kualitas larutan seperti berat jenis, viskositas, $\mathrm{pH}$ larutan, dan kualitas semen berupa motilitas dan viabilitas spermatozoa. Hasil penelitian menunjukkan bahwatemperatur penyimpanan berpengaruh nyata $(\mathrm{P}<0,05)$ terhadap perubahan kualitas pengencer dan kualitas semen domba. Hasil penelitian ini dapat disimpulkan bahwa penyimpanan larutan pengencer pada temperatur $7^{\circ} \mathrm{Cmenghasilkankualitas} \mathrm{pengencer} \mathrm{tris} \mathrm{kuning} \mathrm{telur}$ dankualitas semen domba yang paling baik dibandingkan dengan teknik penyimpanan lainnya.Teknik penyimpanan pengencer pada temperatur $7^{\circ} \mathrm{C}$ memiliki nilai tinggi pada berat jenis $(1,0069(\mathrm{~g} / \mathrm{ml}))$, viskositas $(2,8537(\mathrm{~mm} 2 / \mathrm{s}) /(\mathrm{cSt}))$ dan $\mathrm{pH}(6,5)$, selain itu sperma mampu bertahan selama 13 hari.
\end{abstract}

\section{PENDAHULUAN}

Teknologi inseminasi buatan (IB) telah banyak di manfaatkan oleh peternak untuk membantu proses perkawinan pada ternak. Kualitas yang baik pada semen cair maupun beku sangat diperlukan untuk membantu keberhasilan IB. Proses pengenceran semen menjadi salah satu faktor yang dapat menentukan kualitas semen selama proses penyimpanan dingin maupun beku. Pengencer merupakan campuran bahan bernutrisi yang dapat mempertahankan kualitas spermatozoa. Selain itu pengenceran berfungsi untuk menambah volume semen sehingga semakin banyak jumlah ternak yang dapat di IB (Susilawati, 2011).

Berbagai jenis pengencer semen telah banyak ditemukan, namun pengencer tris kuning telur merupakan jenis pengencer yang paling umum digunakan baik pada semen domba, sapi maupun jenis ternak lain. Penentuan komposisi antara buffer tris dengan kuning telur pada setiap jenis ternak dapat berbeda-beda sesuai dengan kebutuhannya. Pengencer tris terdiri dari beberapa jenis zat penyangga yang dapat mengurangi kerusakan akibat ion hidrogen yang dihasilkan dari aktivitas metabolisme spermatozoa (Salamon 
dan Maxwell, 2000). Teknik penyimpanan pengencer tris kuning telur yang tidak tepat dapat meningkatkan kerusakan pengencer dan kualitas sperma. Selama proses penyimpanan zat-zat yang terkandung dalam pengencer akan mengalami oksidasi sehingga meningkatkan kadar radikal bebas yang dapat merusak spermatozoa (Wiyanti, dkk., 2013).

Kerusakan ini dapat diakibatkan oleh berberbagai faktor salah satunya yaitu temperatur penyimpanan pengencer. Penyimpanan semen dalam pengencer tris kuning telur pada suhu ruang dapat mempertahankan kualitas semen selama 4 jam (Agustian, dkk., 2014), sedangkan penyimpanan semen dalam pengencer tris kuning telur pada suhu $5{ }^{\circ} \mathrm{C}$ dapat mempertahankan kualitas sperma selama 79 jam (Rhoyan, dkk., 2014). Temperatur diketahui dapat mempengaruhi tingkat kecepatan oksidasi pada komponenkomponen kimia organik (Allinger, dkk., 1976). Peningkatan proses oksidasi akan menurunkan kualitas pengencer maupun spermatozoa (Storey, 2008). Berdasarkan pernyataan tersebut bahwa temperatur penyimpanan dapat mempengaruhi kualitas pengencer dan daya tahan hidup spermatozoa. Penelitian ini bertujuan mengetahui perubahan karakteristik pengencer dan kualitas semen domba pada berbagai temperatur penyimpanan.

\section{METODE}

Penelitian dilakukan di Laboratorium Reproduksi Ternak dan Inseminasi Buatan, Fakultas peternakan, UNPAD, Jatinangor.
Penelitian ini merupakan penelitian eksperimental dengan rancangan lingkungan acak lengkap (RAL) dan metode analisis yang digunakan yaitu analisis varian (ANOVA). Data yang diperoleh diolah dengan mencari nilai rata-rata yang kemudiandiuji lanjut menggunakanUji Berganda Duncan untuk mengetahui perbedaan setiap perlakuan (Gaspersz, 2006).

Materi yang digunakan dalam penelitian ini yaitu larutan Tris Kuning Telur dan semen domba lokal jantan berumur 2-3 tahun.Larutan tris kuning telur terdiri dari 1,725 gr kristal Tris (hydroxymethyl) aminomethane, 2,79 gr kristal Fruktosa, 1,555 gr Laktosa dan 0,95 gram asam sitrat monohidrat, $88 \mathrm{ml}$ aquabidestilatadan 20\% kuning telur(Salamon dan Maxwell, 2000). Larutan tris kuning telur yang sudah dibuat dibagi menjadi tiga dan disimpan pada temperatur yang berbeda-beda sebagai perlakuan yaitu 1) penyimpanan pada waterbath temperatur $37^{\circ} \mathrm{C}$ - 2) penyimpanan pada temperatur ruangan. 3) penyimpanan pada refrigerator temperature $5-7{ }^{\circ} \mathrm{C}$. Larutan tris yang telah disimpan selama 24 jam kemudian ditambahkan semen domba lokal untuk menguji kualitas larutan tris tersebut. Variabel yang diamati diantaranya viabilitas sperma, motilitas sperma, perubahan $\mathrm{pH}$ larutan, berat jenis larutan dan viskositas larutan.

\section{HASIL DAN PEMBAHASAN}

\section{Berat Jenis Pengencer Semen pada}

\section{Berbagai Temperatur Penyimpanan}

Hasil pengukuran berat jenis pengencer tris kuning telur yang disimpan pada temperatur yang berbedadapat dilihat pada Tabel 1 . 
Tabel 1. Rataan Berat Jenis Pengencer pada Berbagai Temperatur Penyimpanan

\begin{tabular}{lcrr}
\hline $\begin{array}{c}\text { Temperatur } \\
\text { Peyimpanan } \\
\text { pengencer }\end{array}$ & $\begin{array}{c}\text { Berat pikno + sampel } \\
(\mathrm{g})\end{array}$ & Berat sampel $(\mathrm{g})$ & BJ/Kerapatan $(\mathrm{g} / \mathrm{ml})$ \\
\hline $7^{\circ} \mathrm{C}$ & $26,7638 \pm 0,003$ & $9,8892 \pm 0,003$ & $1,0069 \pm 0,001^{\mathrm{c}}$ \\
$28^{\circ} \mathrm{C}$ & $26,7209 \pm 0,002$ & $9,8499 \pm 0,003$ & $1,0029 \pm 0,001^{\mathrm{a}}$ \\
$37^{\circ} \mathrm{C}$ & $26,7297 \pm 0,002$ & $9,8587 \pm 0,001$ & $1,0038 \pm 0,001^{\mathrm{b}}$ \\
\hline
\end{tabular}

Perbedaan superscript $(\mathrm{a}, \mathrm{b})$ pada baris yang sama menunjukkan perbedaan yang signifikan $(\mathrm{P}<0,05)$

Hasil analisis menunjukkan bahwa perbedaan temperatur penyimpanan pengencer berpengaruh nyata $(\mathrm{P}<0,05)$ terhadap berat jenis larutan tris kuning telur. Berdasarkan hasil pengamatan menunjukan bahwa nilai berat jenis pengencer tris kuning telur pada penyimpanan dingin dengan temperatur $7^{\circ}$ Cnyata lebih tinggi yaitu sebesar $1,0069 \mathrm{~g} / \mathrm{ml}$, sedangkan pada temperatur penyimpanan $28^{\circ} \mathrm{C}$ dan $37^{\circ} \mathrm{C}$ memiliki berat jenis masing-masing sebesar $1,0029 \mathrm{~g} / \mathrm{ml}$ dan $1,0038 \mathrm{~g} / \mathrm{ml}$. Berat jenis pengencer pada setiap temperatur penyimpanan memiliki rataan yang tidak berbeda.

\section{Viskositas Pengencer Semen pada Berbagai}

\section{Temperatur Penyimpanan}

Viskositas pengencer pada berbagai temperatur penyimpanan dapat dilihat pada Tabel 2.

Hasil analisis ragam menunjukkan bahwa perbedaan temperatur penyimpanan berpenga- ruh nyata $(\mathrm{P}<0,05)$ terhadap viskositas pengencer tris kuning telur. Berdasarkan hasil pengamatanmenunjukkan bahwa rataan viskositas pengencer pada temperatur penyimpanan dingin $7^{\circ} \mathrm{C}$ memiliki nilai viskositas nyata lebih tinggi dibandingkan perlakuan lainnya yaitu sebesar 2,8537 $(\mathrm{mm} 2 / \mathrm{s}) /(\mathrm{cSt})$, sedangkan pada penyimpanan dengan temperatur $28^{\circ} \mathrm{C}$ sebesar $1,4663(\mathrm{~mm} 2 / \mathrm{s}) /(\mathrm{cSt})$, dan pada penyimpanan temperatur $\quad 37^{\circ} \mathrm{C}$ sebesar 0,6350 $(\mathrm{mm} 2 / \mathrm{s}) /(\mathrm{cSt})$. Perbedaan viskositas pengencer tris kuning telur pada setiap perlakuan mungkin disebabkan karena kandungan kuning telur dalam pengencer. Menurut hasil penelitian Lee, dkk (2016) diketahui peningkatan waktu dan suhu penyimpanan dapat menyebabkan pemecahan struktur protein kuning telur sehingga mengurangi sifat viskositas larutan.

Tabel 2. Rataan Viskositas Pengencer pada Berbagai Temperatur Penyimpanan

\begin{tabular}{lcccc}
\hline $\begin{array}{c}\text { Temperatur } \\
\begin{array}{c}\text { Peyimpanan } \\
\text { pengencer }\end{array}\end{array}$ & $\begin{array}{c}\text { Waktu } \\
(\text { detik })\end{array}$ & $\begin{array}{c}\text { Kerapatan } \\
(\mathrm{g} / \mathrm{mL})\end{array}$ & $\begin{array}{c}\text { Viskositas } \\
(\mathrm{mm} 2 / \mathrm{s}) /(\mathrm{cSt})\end{array}$ & $\begin{array}{c}\text { Viskositas } \\
(\mathrm{cP} / \mathrm{mPa} \text { *s) }\end{array}$ \\
\hline & & & & \\
$7^{\circ} \mathrm{C}$ & $29,876 \pm 0,258$ & $1,0069 \pm 0,001$ & $2,854 \pm 0,051^{\mathrm{a}}$ & $2,874 \pm 0,051^{\mathrm{a}}$ \\
$28^{\circ} \mathrm{C}$ & $18,064 \pm 0,061$ & $1,0029 \pm 0,001$ & $1,466 \pm 0,004^{\mathrm{b}}$ & $1,471 \pm 0,004^{\mathrm{b}}$ \\
$37^{\circ} \mathrm{C}$ & $9,348 \pm 0,028$ & $1,0038 \pm 0,001$ & $0,635 \pm 0,002^{\mathrm{c}}$ & $0,637 \pm 0,002^{\mathrm{c}}$ \\
\hline
\end{tabular}

Perbedaan superscript $(\mathrm{a}, \mathrm{b})$ pada baris yang sama menunjukkan perbedaan yang signifikan $(\mathrm{P}<0,05)$ 


\section{Tingkat pH Pengencer Semen pada}

\section{Berbagai Temperatur Penyimpanan}

Tris memiliki kemampuan yang efektif dalam mempertahankan $\mathrm{pH}$ dan pada konsentrasi tinggi menghasilkan toksisitas yang rendah (Solihati dkk., 2008). Derajat keasaman atau $\mathrm{pH}$ pengencer yang disimpan pada berbagai temperatur penyimpanan menunjukan hasil pada Tabel 3.

Berdasarkan hasil analisis bahwa perbedaan temperatur penyimpanan pengencer tidak berpengaruh nyata $(\mathrm{P}>0,05)$ terhadap perubahan derat keasamaan $(\mathrm{pH})$ larutan pengencer. Hasil pengamatan dari beberapa kali ulangan menunjukan bahwa $\mathrm{pH}$ pengencer tris kuning telur pada temperatur penyimpanan $7^{\circ} \mathrm{C}$ sebesar 6,5 dan hingga hari ke $14 \mathrm{pH}$ tidak menunjukan perubahan. Namun $\mathrm{pH}$ pengencer pada temperatur penyimpanan $28^{\circ} \mathrm{C}$ sebesar 6,5 dan mengalami penurunan hingga menunjukan pH 5 pada hari keempat. Hal ini juga terjadi pada pengencer tris yang disimpan pada temperatur $37^{\circ} \mathrm{C}$ yaitu pada hari ketiga $\mathrm{pH}$ pengencer mengalami penurunanhingga skala 5.Perubahan $\mathrm{pH}$ pada pengencer yang disimpan pada berbagai temperatur mungkin diakibatkan oleh kandungan kuning telur. Menurut hasil penelitian Lee, dkk (2016) diketahui bahwa peningkatan suhu penyimpanan berpengaruh terhadap peningkatan $\mathrm{pH}$ kuning telur. Perubahan $\mathrm{pH}$ pada larutan mungkin bukan dipengaruhi oleh suhu, namun lebih dipengaruhi oleh periode penyimpanan.

\section{MotilitasDan ViabilitasSperma pada \\ Berbagai Temperatur Penyimpanan}

Setiap bahan pengencer yang baik harus menyediakan sumber energi untuk proses metabolisme, dan dapat mempertahankan tekanan osmotik dan pH (Rehman dkk, 2013) dapat memperkecil tingkat penurunan nilai motilitas (gerak progresif) sperma sehingga dapat memeperpanjang lama waktu penyimpanan pasca pengenceran (Zega dkk, 2015). Pengaruh temperatur penyimpanan pengencer terhadap motilitas dan viabilitas dapat dilihat pada tabel 4.

Tabel 3. Rataan Ph Pengencer pada Berbagai Temperatur Penyimpanan

\begin{tabular}{|c|c|c|c|c|c|c|c|c|c|c|c|c|c|c|}
\hline \multirow{2}{*}{$\begin{array}{c}\text { Temperatur } \\
\text { Peyimpanan } \\
\text { pengencer }\end{array}$} & \multicolumn{14}{|c|}{$\mathrm{pH}$ hari ke - } \\
\hline & 1 & 2 & 3 & 4 & 5 & 6 & 7 & 8 & 9 & 10 & 11 & 12 & 13 & 14 \\
\hline $7^{\circ} \mathrm{C}$ & 6,5 & 6,5 & 6,5 & 6,5 & 6,5 & 6,5 & 6,5 & 6,5 & 6,5 & 6,5 & 6,5 & 6,5 & 6,5 & 6,5 \\
\hline $28^{\circ} \mathrm{C}$ & 6,5 & 6 & 5,5 & 5 & 5 & 5 & 5 & 5 & 5 & 5 & 5 & 5 & 5 & 5 \\
\hline $37^{\circ} \mathrm{C}$ & 6,5 & 5,5 & 5 & 5 & 5 & 5 & 5 & 5 & 5 & 5 & 5 & 5 & 5 & 5 \\
\hline
\end{tabular}

$\underline{\text { Tabel 4. Temperatur Penyimpanan Pengencer terhadap Motilitas dan Viabilitas Sperma }}$

\begin{tabular}{llcc}
\hline \multirow{2}{*}{ Variabel } & \multicolumn{3}{c}{ Temperatur Penyimpanan $\left({ }^{\circ} \mathrm{C}\right)$} \\
\hline Motilitas (\%) & 7 & 28 & 37 \\
Viabilitas (hari) & $67,4 \pm 1,82^{\mathrm{a}}$ & $79,4 \pm 1,52^{\mathrm{b}}$ & $89 \pm 1,58^{\mathrm{c}}$ \\
\hline & $13,0 \pm 1,00^{\mathrm{a}}$ & $2,8 \pm 0,45^{\mathrm{b}}$ & $1,2 \pm 0,45^{\mathrm{c}}$ \\
\hline
\end{tabular}

Perbedaan superscript $(a, b)$ pada baris yang sama menunjukkan perbedaan yang signifikan $(P<0,05)$ 
Hasil analisis menunjukkan bahwa temperatur penyimpanan berpengaruh nyata $(\mathrm{P}<0,05)$ terhadap motilitas dan viabilitas sperma domba. Berdasarkan hasil pengamatan bahwa kualitas pengencer tris kuning teluryang disimpan pada temperatur $7^{\circ} \mathrm{C}$ ratarata menunjukan kualitas yang baik hingga hari ke-13. Hasil uji Duncan menunjukan bahwa motilitas sperma pada pengencer yang disimpan di temperatur $7^{\circ} \mathrm{C}$ memiliki rataan viabilitas nyata lebih tinggi $(\mathrm{P}<0,05)$ dibandingkan dengan perlakuan lainnya. Hal ini ditunjukkan dengan adanya pergerakan atau motilitas sperma saat semen dimasukan kedalam pengencer tsb. Kualitas yang berbeda ditunjukkan oleh pengencer tris kuning telur yang disimpan pada $28^{\circ} \mathrm{C}$ dimana kualitas pengencer pada hari ke-3 mulai menurun sehingga ketika semen dimasukan kedalam pengencer terjadi kematian pada sperma. Hal ini juga terjadi pada pengencer tris kuning telur yang disimpan pada temperatur $37^{\circ} \mathrm{C}$ menunjukan bahwa sperma yang dimasukan ke pengencer masih dapat hidup pada hari ke1, akan tetapi hari ke-2 menunjukkan kematian pada sperma. Hasil ini tidak sejalan dengan hasil penelitian Kusumawati, dkk (2016) yang menunjukkan bahwa daya hidup sperma yang disimpan pada suhu $5^{\circ} \mathrm{C}$ dan suhu ruang masing-masing mampu bertahan selama 7 hari, namun terdapat perbedaan persentase motilitas. Pengencer yang disimpan pada temperatur $5^{\circ} \mathrm{C}$ padahari ke-7 memiliki motilitas sebesar $37,4 \%$ sedangkan pada suhu ruang sebesar $40,4 \%$. Jika diamati berdasarkan
$\mathrm{pH}$ pengencer hasil penelitian ini sesuai dengan hasil penelitian Morton, dkk., 2009yang menyatakan bahwa sperma tetap motil selama 24 jam pada pengencer tris dengan $\mathrm{pH}$ 6,9. Sperma akan kehilangan motilitasnya antara 4 hingga 12 jam penyimpanan jika pengencer Tris memiliki $\mathrm{pH}$ 5,5 .

Hasil uji duncan menunjukkan bahwa rataan motilitas sperma pada setiap teknik temperatur penyimpanan pengencer tris kuning telur berbeda nyata $(\mathrm{P}<0,05)$, dimana motilitas sperma pada pengencer yang disimpan pada temperatur $37^{\circ} \mathrm{C}$ lebih rendah dibandingkan perlakuan lainnya. Hasil pengamatan menunjukkan bahwa kemampuan sperma dalam pengencer tris kuning telur yang disimpan pada temperatur $7^{\circ} \mathrm{C}$ sebesar $67,4 \%$ pada hari pertama dan dapat bertahan hingga hari ke-7 dengan motilitas sebesar 39,6\%. Semen yang dimasukan pada pengencer dengan temperatur penyimpanan $7^{\circ} \mathrm{C}$ setiap harinya mengalami penurunan motilitas sebesar 4-5\%, sedangkan pengencer yang disimpan pada temperatur $28^{\circ} \mathrm{C}$ dan $37^{\circ} \mathrm{C}$ menunjukkan penurunan motilitas sperma yang signifikan. Hasil pengamatan motilitas hari pertama pada pengencer tris kuning telur yang disimpan pada temperatur $28^{\circ} \mathrm{C}$ sebesar $79,4 \%$ dan hanya bertahan hingga hari ke-2 sebesar 35,2\%, sedangkan motilitas sperma pada pengenceryang disimpanpada temperatur $37^{\circ} \mathrm{C}$ hanya dapat bertahan selama satu haridengan motilitas sebesar $89 \%$. 
Tabel 5.Temperatur Penyimpanan Pengencer terhadap Penurunan Motilitas Sperma

\begin{tabular}{|c|c|c|c|c|c|c|c|}
\hline \multirow{2}{*}{$\begin{array}{c}\text { Temperatur Peyimpanan } \\
\text { pengencer }\end{array}$} & \multicolumn{7}{|c|}{ Motilitas hari ke- } \\
\hline & 1 & 2 & 3 & 4 & 5 & 6 & 7 \\
\hline & \multicolumn{7}{|c|}{------------------_\%------------------- } \\
\hline $7^{\circ} \mathrm{C}$ & 67,4 & 62,6 & 58,8 & 53,4 & 47,2 & 43,8 & 39,6 \\
\hline $28^{\circ} \mathrm{C}$ & 79,4 & 35,2 & 2 & 0 & 0 & 0 & 0 \\
\hline $37^{\circ} \mathrm{C}$ & 89 & 0 & 0 & 0 & 0 & 0 & 0 \\
\hline
\end{tabular}

Perbedaan temperatur penyimpanan pengencer tris kuning telur menyebabkan perbedaan motilitas pada hari pertama. Hal ini terjadi karena semakin menurunnya temperatur penyimpanan menyebabkan penurunan viabilitas sperma. Pada saat proses penampungan semen, sperma berada pada suhu ruang berkisar antara $27-28^{\circ} \mathrm{C}$., sehingga saat menggunakan pengencer yang disimpan pada temperatur $28{ }^{\circ} \mathrm{C}$ motilitas akan tetep terjaga. Namun, ketika semen dimasukan kedalam pengenceryang disimpan pada temperatur $7^{\circ} \mathrm{C}$ mengalami penurunan motilitas yang disebabkan perubahan temperatur. Perubahan suhu dari suhu ruang menjadi $5^{\circ} \mathrm{C}$ menyebabkan spermatozoa harus beradaptasi dan bahkan terjadi penurunan motilitas. Tingkat metabolisme sperma akan menurun seiring dengan adanya penurunan temperatur penyimpanan semen. Proses metabolisme sperma yang menurun menyebabkan produksi energi yangdihasilkan sperma ikut menurun dan berdampak pada kemampuan bergerak sperma (Rizal dan Herdis, 2010; Susilawati, 2011).

\section{SIMPULAN}

Temperatur penyimpanan pengencer tris kuning telur berpengaruh terhadap karakteristik larutan yang meliputi $\mathrm{pH}$, berat jenis dan viskositas pengencer. Selain itu perubahan karakteristik pengencer tris akibat proses penyimpanan dapat mempengaruhi motilitas dan viabiltas sperma. Teknik penyimpanan pengencer pada temperatur dingin merupakan metode yang tepat untuk mempertahankan karakteristik dari bahan pengencer tris kuning telur sehingga viabilitas sperma dapat bertahan lama.

\section{DAFTAR PUSTAKA}

Allinger, N.1., Cava, M., De jongh, D.C., Johnson, C.R., Lebel, A., and Steven, C.L.1976. Organic Chemistry, $2^{\text {nd }}$ edition, Worth Publishers Inc., New York.

Agustian, M. F., M.N. Ihsan dan N. Isnaini. 2014. Pengaruh Lama Simpan Semen dengan Pengencer Tris Aminomethan Kuning Telur pada Suhu Ruang terhadap Kualitas Spermatozoa Kambing Boer. J. Ternak Tropika Vol. 15, No.2: 1-6.

Gaspersz. 2006. Teknik Analisis dalam Penelitian Percobaan.Tarsito. Bandung. Hal $62-84$.

Kusumawati, E.D., H. Leondro., A. T. N. Krisnaningsih., T. Susilawati., N. Isnaini dan R. Widhad. 2016. Pengaruh Suhu dan Lama Simpan Semen Segar terhadap Motilitas dan Abnormalitas Spermatozoa Kambing Peranakan Etawa (PE). Seminar Nasional Hasil Penelitian, Universitas Brawijaya: 199208. 
Lee, M.H., E.J. Cho., E.S. Choi dan S.H. Sohn. 2016. The Effect of Storage Period and Temperature on Egg Quality in Commercial Eggs. Korean J. Poult. Sci. Vol.43, No.1: 31-38.

Morton K. M., Z.Gibb., M. Bertoldo dan W.M.C. Maxwell. 2009. Effect of Diluent, Dilution Rate and Storage Temperature on Longevity and Functional Integrity of Liquid Stored Alpaca (Vicugna Pacos) Semen. Journal of Camelid Science $2:$ 15-25.

Rehman, F., Zhao, M.A Shah, M.S. Qureshi, X. Wang. 2013. Semen Extenders And Artificial Insemination In Ruminants. Veterinaria 2013, 1: 1-8.

Rhoyan, Y.H., T.D. Lestari, dan R. Setiawan. 2014. Kualitas Semen Cair Dingin Domba Garut pada Tiga Jenis Larutan Pengencer. Jurnal Ilmu Ternak Vol. 1, No. 12: 64- 68.

Rizal dan Herdis. 2010. Peranan Antioksidan dalam Meningkatkan Kualitas Semen Beku. Wartazoa, Vol 20 No 3: 139-145.

Salamon, S dan W.M.C. Maxwell. 2000. S. Storage of Ram Semen. Animal Reproduction Science 62: 77-111.
Solihati N., R. Idi, S.D. Rasad, M. Rizal dan M Fitriati. 2008. Kualitas Sperma Cauda Epididimis Sapi Peranakan Ongole (PO) Dalam Pengencer Susu, Tis Dan Sitrat Kuning Telur Pada Penyimpanan $4-5^{\circ} c$. Jurnal animal production. Vol. 10. 1: 22-29.

Susilawati. T. 2011. Spermatologi. Universitas Brawijaya Press. Malang : 15-45.

Storey, B.T. 2008. Mammalian Sperm Metabolism: Oxygen and Sugar, Friend and Foe. International Journal Developmental Biology 52: 427-437

Wiyanti, D. C., N. Isnaini dan P. Trisunuwati. 2013. Pengaruh Lama Simpan Semen dalam Pengencer Nacl Fisiologis pada Suhu Kamar terhadap Kualitas Spermatozoa Ayam Kampung (Gallus Domesticus). Jurnal Kedokteran Hewan Vol. 7 No. 1: 53-55.

Zega, I., S. Ilyas, S. Hutahaean. 2015. Kualitas Spermatozoa Sapi Limousin Dalam Pengencer TwoStatm Extender Dengan Suplementasi Kuning Telur Bebek Selama Penyimpanan Pada Refrigrator. Jurnal Biosains Vol. 1 No. 3 : 66-72. 